\title{
Second tier non-invasive prenatal testing in a regional prenatal diagnosis service unit: a retrospective analysis and literature review
}

\author{
Vivian KS Ng *, Avis L Chan, WL Lau, WC Leung
}

\section{A B S T R A C T}

Introduction: The Hong Kong Hospital Authority has newly introduced a new Down's syndrome screening algorithm that offers free-of-charge noninvasive prenatal testing (NIPT) to women who screen as high risk. In preparation for this publicfunded second tier NIPT service, the present study was conducted to retrospectively analyse women eligible for NIPT and to review the local literature.

Methods: Our retrospective study included women screened as high risk for Down's syndrome (adjusted term risk $\geq 1: 250$ ) during the period of 1 January 2015 to 31 December 2016. We performed descriptive statistics and multivariable logistic regression to examine the factors associated with women's choice between NIPT and invasive testing. We also reviewed existing local literature about second tier NIPT.

Results: The study included 525 women who screened positive: $67 \%$ chose NIPT; $31 \%$ chose invasive diagnostic tests; and $2 \%$ declined further testing. Our literature review showed that in nonresearch (self-financed NIPT) settings, NIPT

This article was published on 22 Jan 2020 at www.hkmj.org. uptake rates have been increasing since 2011.

Nulliparity, first trimester status, higher education,

maternal employment, and conception by assisted reproductive technology are common factors associated with self-financed NIPT after positive screening. Among women choosing NIPT, the rates of abnormal results have typically been around $8 \%$ in studies performed in Hong Kong.

Conclusion: Implementation of second tier NIPT in the public setting is believed to be able to improve quality of care. We expect that the public in Hong Kong will welcome the new policy.

\section{Hong Kong Med J 2020;26:10-8}

https://doi.org/10.12809/hkmj198197

\footnotetext{
${ }^{1}$ VKS Ng *, MB, ChB, FHKAM (Obstetrics and Gynaecology)

1,2 AL Chan, MB, BS, FHKAM (Obstetrics and Gynaecology)

${ }^{1}$ WL Lau, MB, BS, FHKAM (Obstetrics and Gynaecology)

${ }^{1}$ WC Leung, MD, FHKAM (Obstetrics and Gynaecology)
}

${ }^{1}$ Department of Obstetrics and Gynaecology, Kwong Wah Hospital, Yaumatei, Hong Kong

2 Department of Pediatrics, Stanford University School of Medicine, Palo Alto, California, United States

* Corresponding author: vivian_nks@hotmail.com

New knowledge added by this study

A comprehensive review of all local studies in Hong Kong (including ours) that summarise the increasing trend of women choosing second tier non-invasive prenatal testing (NIPT) after high-risk Down's syndrome screening results; factors associated with choice of NIPT; and the percentages of abnormal NIPT results.

Implications for clinical practice or policy

- The new Hospital Authority policy of offering publicly funded second tier NIPT for high-risk Down's syndrome screening results will be feasible, beneficial, and welcomed by pregnant women and their partners.

\section{Introduction}

Prenatal diagnostic tests for Down's syndrome have been changing dramatically in recent decades. In the $1990 \mathrm{~s}$, women aged $\geq 35$ years at confinement of pregnancy were regarded as the 'high-risk' group in terms of carrying babies with Down's syndrome. They were offered direct invasive procedures that involved using a needle to puncture the amniotic sac (amniocentesis) or placenta (chorionic villus sampling) to rule out chromosomal abnormalities. Although these tests are diagnostic and accurate, they have procedure-related miscarriage risks of $1 / 100$ to $1 / 200 .{ }^{1}$ Indeed, the majority of these cases undergoing such invasive procedures are normal pregnancies, and this age-based approach imposed avoidable risks on otherwise normal babies. Later, Down's syndrome screening for nuchal translucency (NT) and maternal serum markers was introduced to women of advanced maternal age ( $\geq 35$ years). Since 1 July 2010, universal Down's syndrome screening has been offered in all public obstetrics units in Hong Kong. ${ }^{2}$ All pregnant women at appropriate gestation are offered informed prenatal screening choices irrespective of their age. Those women who are screened as high risk (adjusted term risk $\geq 1: 250$ ) were counselled for either invasive diagnostic prenatal tests (chorionic villus sampling versus amniocentesis) or expectant management 
without further tests. Ultrasound examination for fetal abnormalities was performed regardless of women's choices. This measure has significantly reduced unnecessary invasive procedures for women of advanced maternal age without introducing any other risk factors. ${ }^{3}$ However, the sensitivity and specificity of first or second trimester Down's syndrome screening tests are only about 90\%, ${ }^{4}$ and false positive cases and accidental findings of chromosomal and structural abnormalities may put women at risk of further unnecessary procedures.

The discovery of the presence of cell-free fetal DNA in maternal plasma by Professor Dennis Lo in 1997 was a remarkable breakthrough in prenatal screening. ${ }^{5-7}$ In 2011, non-invasive prenatal testing (NIPT) became commercially available in Hong Kong as a self-financed examination. Following positive Down's syndrome screening, women are now given an additional choice, NIPT, in addition to the traditional approach with either invasive diagnostic procedures or expectant management. The introduction of this technology has made a significant impact on choices and decisions by obstetricians, healthcare policy makers, and pregnant women. ${ }^{8}$

Compared with conventional screening, which has a $90 \%$ detection rate of Down's syndrome and a $5 \%$ false positive rate, ${ }^{1}$ NIPT achieves a higher detection rate $(99 \%)$ and a lower false positive rate (as low as 0.1\%). ${ }^{9}$ Even though NIPT costs $>\mathrm{HK} \$ 5000$, it is generally accepted by clinicians and pregnant women because of its accuracy and safety. In December 2019, the Hong Kong Hospital Authority introduced a publicly funded (free-ofcharge) second tier of NIPT to pregnant women who are screened positive/high risk by the Down's syndrome screening tests. While transitioning to the new healthcare policy (Fig 1), we performed this study to analyse data from a large sample in our centre (which has approximately 5000 annual deliveries) and summarise local NIPT study findings from Hong Kong. We hypothesised that the general population and healthcare providers in Hong Kong are ready for and supportive of the new policy and that the prospective NIPT uptake rate will be very high.

\section{Methods}

This retrospective cohort study was conducted in a government-funded regional obstetrics unit in Hong Kong that manages approximately 5000 annual deliveries. All women who presented to our obstetrics unit were eligible for Down's syndrome screening, should their gestation meet the screening criteria. The Down's syndrome screening programme is funded by the government and therefore free of charge to all registered pregnant women. Pregnant women are offered either first trimester combined
區域公立醫院產前診斷中心的第二層無創性胎兒 染色體篩查檢測：基於回溯分析與本地文獻 回顧的視角

\author{
吳坤蒨、陳麗玲、劉偉霖、梁永昌
}

引言 : 香港醫院管理局剛推出一種新唐氏綜合症篩查方法, 該方法將 為篩查呈高風險的婦女提供免費無創性胎兒染色體篩查檢測（NIPT）

。在籌備該項作為公共服務的第二層NIPT篩查服務之時, 本研究回溯 性分析符合NIPT條件的婦女以及回顧本地相關文獻。

方法：這項回溯性研究納入2015年1月1日至2016年12月 31 日期間篩 查呈高風險的女性（即經調整唐氏風險為 $\geq 1: 250$ ）。我們通過描述性 統計和多元因素邏輯迴歸分析, 檢視與女性選擇NIPT或侵入性測試的 相關因素, 並且回顧有關第二層NIPT篩查的現有本地文獻。

結果：這項研究包括525位唐氏篩查呈陽性的婦女, 其中 $67 \%$ 選擇 NIPT、 $31 \%$ 選擇侵入性診斷測試，2\%拒絕進一步測試。文獻評述的 結果表明, 在非研究背景下（即自資NIPT）, NIPT的選取率自2011 年以來不斷上升。從未生育過的、初期妊娠、曾受高等教育、孕婦 在職, 以及通過輔助生育技術受孕為陽性篩查後自資NIPT常見的 因素。在選擇NIPT的婦女中, 香港當地的研究中異常結果率一般在 $8 \%$ 。

結論：在公立醫院實施第二層NIPT篩查可提高服務質量。我們預期香 港市民會歡迎此項新政策。

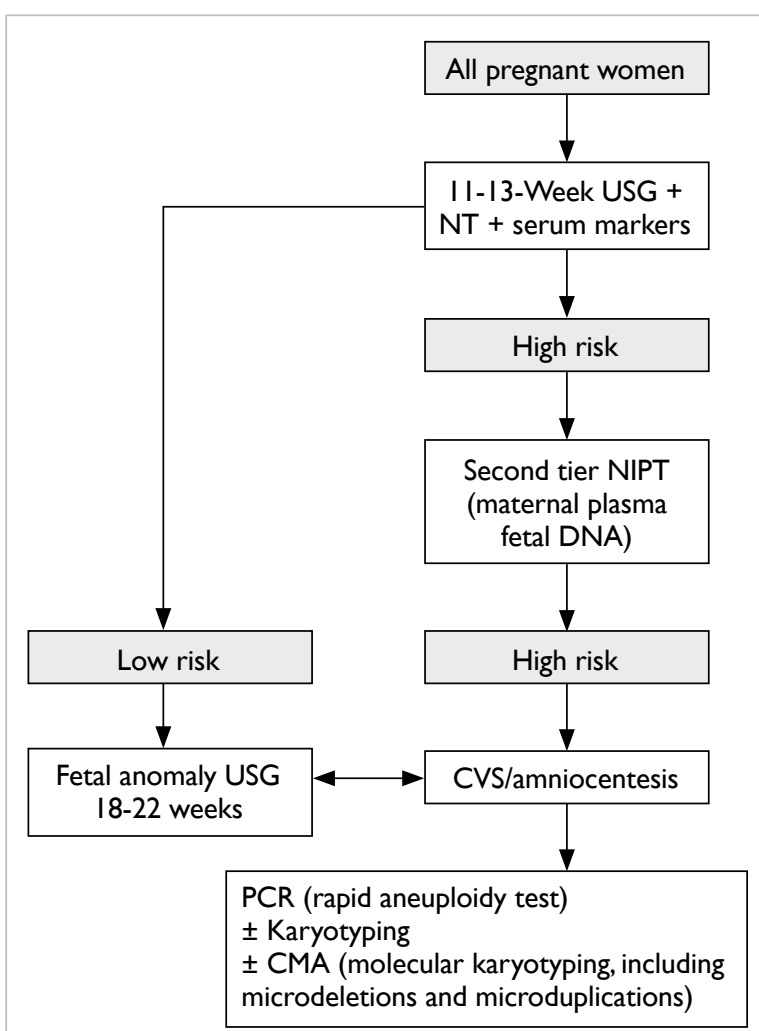

FIG I. New algorithm for prenatal diagnosis of Down's syndrome in Hong Kong

Abbreviations: CMA = chromosomal microarray; CVS = chorionic villus sampling; NIPT = non-invasive prenatal testing; $\mathrm{NT}=$ nuchal translucency; $\mathrm{PCR}=$ polymerase chain reaction; USG = ultrasound 
Down's syndrome screening at 11 to 13 weeks of gestation or second trimester screening at 16 to 19 weeks of gestation. In all Hospital Authority units, first trimester combined Down's syndrome screening measures and analyses the woman's age, NT thickness, pregnancy-associated plasma protein $\mathrm{A}$, and free beta human chorionic gonadotropin, while second trimester biochemical screening includes the woman's age, total human chorionic gonadotropin, alpha-fetoprotein, and unconjugated estriol (uE3) [uE3 has been included in biochemical screening since late 2016 to improve screening detection rates of trisomy 13,18 , and 21]. The result is regarded as high risk if the adjusted term risk ratio for trisomy 21,18 , and/or 13 is $\geq 1: 250$. Women who are screened as high risk are notified and counselled for further management options by trained nurses or midwives who are certified for ultrasound scanning by the Hospital Authority and Fetal Medicine Foundation. These women are offered the following informed choices: (1) publicly funded invasive tests; (2) self-financed NIPT; or (3) decline further tests. The procedure-related risks of miscarriage are quoted as $1 \%$ in chorionic villus sampling and $0.5 \%$ in amniocentesis. ${ }^{1}$ In the presence of thickened $\mathrm{NT}$, especially those $\geq 3.5 \mathrm{~mm}$, women were offered the option of direct invasive testing, as that finding indicates an increased risk of microdeletions or microduplications. Regardless of their choices, detailed ultrasound examination is arranged at 19 to 22 weeks of gestation in women screened as high risk to screen for any fetal structural abnormalities. If ultrasound abnormalities are detected, women who have chosen NIPT or declined further tests are counselled again for invasive diagnostic tests to rule out chromosomal or genetic abnormalities.

Pregnant women screened with high-risk results for trisomy 21,18 , and/or 13 by the universal Down's syndrome screening programme during the period of 1 January 2015 to 31 December 2016 (2 years) were included in this study. We retrieved their demographic (maternal age, education level, race) and clinical (obstetric history, history of abnormal pregnancy, family history, ultrasound findings, Down's syndrome screening test results, woman's choice of further tests after positive screening) details from the Clinical Management System, Electronic Patient Record, Antenatal Record System, and our written records. Descriptive data (counts and percentages) were presented in tables and flowcharts. Bivariate analysis of Chi squared or Fisher's exact tests was performed to identify factors associated with women's choice between NIPT and invasive tests. Two-tailed $\mathrm{P}$ values $<0.05$ were considered statistically significant. We included all statistically significant factors in a multivariable logistic regression model with woman's choice as the outcome. Variables that remained statistically significant were regarded as factors that were independently associated with the woman's choice. The hypothesis was tested by comparing our study's results with the findings of other studies in Hong Kong about NIPT uptake over time. Data were analysed using SPSS (Windows version 23.0; IBM Corp, Armonk [NY], United States).

\section{Results}

From 1 January 2015 to 31 December 2016, 9276 women underwent Down's syndrome screening in our unit. A total of $525(6 \%)$ women were screened positive or at high risk of trisomy 21,18 , and/or 13. Table 1 shows the demographic and clinical characteristics of the screened positive women in our study. Among them, 318 (61\%) women were aged $\geq 35$ years at their estimated date of confinement. Almost all women were Chinese (512/525, 98\%), and the remaining women were from a variety of races. Regarding education level, almost half of these women $(49 \%)$ had achieved secondary school level, and one third had achieved tertiary school level. The education level of $12 \%$ of them was unknown. The vast majority of women (>95\%) in this study had no significant family history or personal history of abnormal pregnancy or genetic diseases. Those with significant family history or personal history of abnormal pregnancy were family history of mental retardation $(n=2)$, trisomy $21(n=1)$, Emmanuel syndrome $(n=1)$, and not specified $(n=1)$. Around one third of women in this study had gravidity $\geq 3$ (37\%), and nearly half of them were nulliparous (46\%). Most of them were conceived naturally (94\%).

For the index pregnancy, 459 (87\%) women and $66(13 \%)$ women had the Down's syndrome screening performed during the first and second trimester, respectively. Over $80 \%$ of screened positive women was positive for any one of trisomy 21, 18, or 13 . For those with NT measured in the screening, $80 \%$ of women had NT $<3 \mathrm{~mm}$, and $10 \%$ had NT of $\geq 3.5$ $\mathrm{mm}$. The distribution of the trisomy 21 risk ratio was uniform and even.

After high-risk results from Down's syndrome screening, $67 \%$ of women chose NIPT; $31 \%$ chose invasive diagnostic tests; and $2 \%$ declined further testing. Figure 2 shows a detailed flowchart of women's decisions for further testing upon positive Down's syndrome screening. Out of 351 women who opted for NIPT after high-risk screening results, 328 (93\%) had normal NIPT results, while 23 (7\%) had abnormal results. The abnormal results included trisomy 21 , trisomy 18 , trisomy 13 , sex chromosome-related, others (69XXX; dup (3q26.1$\mathrm{q} 29,31 \mathrm{M})$ and del (5q15.33-p14.1,22M); increased uptake chromosome 9), and non-reportable $(n=2)$. Of the 23 women with abnormal NIPT results, 21 proceeded to invasive procedures; one miscarried prior to invasive procedures; and one underwent 
TABLE I. Demographic characteristics, clinical characteristics, and Down's syndrome screening results of 525 women with positive screening

\begin{tabular}{|c|c|}
\hline & $\begin{array}{l}\text { No. (\%) of } \\
\text { women }\end{array}$ \\
\hline \multicolumn{2}{|l|}{ Age (years) } \\
\hline$<35$ & 207 (39.4\%) \\
\hline$\geq 35$ & $318(60.6 \%)$ \\
\hline \multicolumn{2}{|l|}{ Education } \\
\hline Primary & $14(2.7 \%)$ \\
\hline Secondary & $256(48.8 \%)$ \\
\hline Tertiary & $193(36.8 \%)$ \\
\hline Unknown & $62(11.8 \%)$ \\
\hline \multicolumn{2}{|l|}{$\begin{array}{l}\text { Family history of genetic or chromosomal } \\
\text { disorders }(n=523)^{\star}\end{array}$} \\
\hline No & $518(99.0 \%)$ \\
\hline Yes & $5(1.0 \%)$ \\
\hline \multicolumn{2}{|l|}{ History of abnormal pregnancy } \\
\hline No & $514(97.9 \%)$ \\
\hline Yes & $11(2.1 \%)$ \\
\hline \multicolumn{2}{|l|}{ Race } \\
\hline Chinese & $512(97.5 \%)$ \\
\hline Filipino & $3(0.6 \%)$ \\
\hline South Asian & $5(1.0 \%)$ \\
\hline Other Asian countries & $4(0.8 \%)$ \\
\hline Caucasian & $1(0.2 \%)$ \\
\hline \multicolumn{2}{|l|}{$\begin{array}{l}\text { Conception by assisted reproductive } \\
\text { technology }\end{array}$} \\
\hline No & $492(93.7 \%)$ \\
\hline Yes & $33(6.3 \%)$ \\
\hline \multicolumn{2}{|l|}{ Gravidity } \\
\hline$<3$ & $331(63.0 \%)$ \\
\hline$\geq 3$ & $194(37.0 \%)$ \\
\hline \multicolumn{2}{|l|}{ Parity } \\
\hline 0 & $239(45.5 \%)$ \\
\hline$>0$ & $286(54.5 \%)$ \\
\hline \multicolumn{2}{|l|}{ Time at Down's syndrome diagnosis } \\
\hline 1st trimester & 459 (87.4\%) \\
\hline 2nd trimester & $66(12.6 \%)$ \\
\hline \multicolumn{2}{|l|}{ Down's syndrome positive multiplicity } \\
\hline Any one of trisomy 13,18 and 21 positive & $431(82.1 \%)$ \\
\hline More than one positive & $94(17.9 \%)$ \\
\hline \multicolumn{2}{|l|}{ Nuchal translucency thickness, $\mathrm{mm}(\mathrm{n}=524)$} \\
\hline$<3$ & $420(80.2 \%)$ \\
\hline 3-3.49 & $48(9.2 \%)$ \\
\hline$\geq 3.5$ & $56(10.7 \%)$ \\
\hline \multicolumn{2}{|l|}{ Trisomy 21 adjusted term risk, reciprocal } \\
\hline $1-9$ & $97(18.5 \%)$ \\
\hline $10-99$ & $180(34.3 \%)$ \\
\hline $100-199$ & $165(31.4 \%)$ \\
\hline $200-250$ & $83(15.8 \%)$ \\
\hline \multicolumn{2}{|l|}{ Prenatal testing $(n=522)^{\star}$} \\
\hline Declined testing & $11(2.1 \%)$ \\
\hline Invasive diagnostic test & $160(30.7 \%)$ \\
\hline Non-invasive prenatal test & $351(67.2 \%)$ \\
\hline
\end{tabular}

termination of pregnancy directly. The diagnosis was confirmed by diagnostic tests in 16 cases: 14 cases ended up with termination of pregnancy; one continued pregnancy (47XYY); and one miscarried afterwards (69XXX). The remaining five women who had invasive diagnostic tests following high-risk NIPT $(n=3)$ and non-reportable NIPT $(n=2)$ were found normal by karyotyping.

There were 328 women with normal NIPT results. However, 15 of them still required invasive procedures for reasons of maternal anxiety $(n=3)$, fetal gender confirmation $(n=1)$, and sonographic abnormalities detected during anomaly scans $(\mathrm{n}=11)$. The 11 women with ultrasound abnormalities all proceeded to invasive procedures. The ultrasound findings, karyotypes, and pregnancy outcomes of these women are shown in Table 2.

Between women choosing NIPT and invasive diagnostic procedures, the factors of maternal education, conception by assisted reproductive technology, gravidity, parity, first trimester, trisomy risks, and NT reached statistically significant difference (Table 3). After adjusting for all these variables in the logistic regression model, only higher maternal education $(\mathrm{P}=0.04)$, gravidity $<3(\mathrm{P}<0.001)$, nulliparity $(\mathrm{P}=0.03)$, and examination during the first trimester $(\mathrm{P}<0.001)$ were associated with higher NIPT uptake.

\section{Discussion}

Although NIPT was self-financed, increasing NIPT uptake rates since 2011 reported by studies from Hong Kong support our hypothesis that pregnant women are supportive of contingent NIPT after positive Down's syndrome screening tests. The uptake rate of self-financed NIPT has increased from $20 \%$ (95\% confidence interval $[\mathrm{CI}]=18 \%-24 \%$; in Poon et al's study, 2011-2012 ${ }^{10}$ ) to $29 \%$ (95\% $\mathrm{CI}=26 \%-32 \%$; in Chan et al's study, 2012-2013 ${ }^{11}$ ) to $67 \%$ (95\% CI=63\%-71\%) in our study, 2015-2016. We observed a steep increase in the NIPT uptake rate in our unit (from $23 \%$ in 2012 to $71 \%$ in 2016), ${ }^{12}$ and a corresponding rise has been observed in other local public obstetrics units, ${ }^{13}$ despite the fact that women had to pay for the cost of NIPT. A multi-centred survey-based study performed in Hong Kong showed that $>90 \%$ of women favouring NIPT after positive Down's syndrome screening were willing to pay for the test. ${ }^{14}$ This study also found that higher income was an independent predictor of women's choice for NIPT. Our study did not include household income because the missing rate is very high $(>50 \%)$. Low or non-response on sensitive issues such as income and wealth has been well documented in the literature. ${ }^{15}$ If cost is eliminated as a factor, we would expect the majority of women to choose NIPT as a contingent test, as projected by Lo et $\mathrm{al}^{13}$ in $2015-2016$ and Cheng et $\mathrm{al}^{16}$ in 2015-2016. In those studies, NIPT 


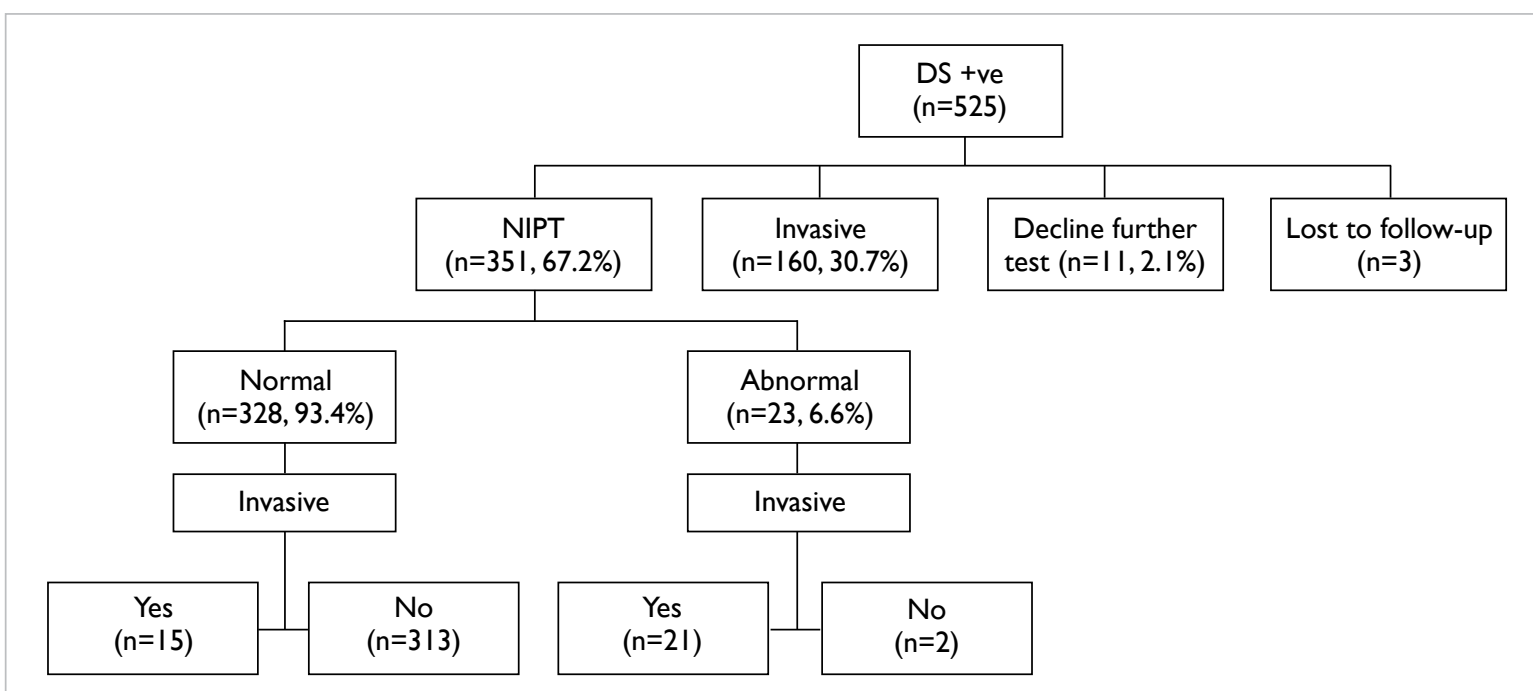

FIG 2. Flowchart of women's decisions about further testing upon positive Down's syndrome screening Abbreviations: DS = Down's syndrome screening; NIPT = non-invasive prenatal testing

TABLE 2. Eleven cases with normal non-invasive prenatal test results but sonographic abnormalities

\begin{tabular}{|c|c|c|c|}
\hline NIPT & Ultrasound abnormalities & Invasive test results & Outcome \\
\hline Low risk & $\begin{array}{l}\text { Single umbilical artery, early-onset IUGR, } \\
\text { hypospadias }\end{array}$ & Amnio: normal & Liveborn \\
\hline Low risk* & VSD & CVS: trisomy 13 & TOP \\
\hline Low risk & Early-onset IUGR & Amnio: normal & Liveborn \\
\hline Low risk & Thick nuchal translucency & CVS: normal & Liveborn \\
\hline Low risk & Increased cardiothoracic ratio & $\begin{array}{l}\text { Amnio: normal; alpha- } \\
\text { thalassaemia major }\end{array}$ & TOP \\
\hline Low risk & Thick nuchal translucency & CVS: normal & Liveborn \\
\hline Low risk & $\begin{array}{l}\text { Dextrocardia, AVSD, posterior fossa cyst, } \\
\text { oligohydramnios }\end{array}$ & Amnio: $69 X X X$ & TOP \\
\hline Low risk & Short long bones, IUGR & $\begin{array}{l}\text { Amnio: normal } \\
\text { Placental tissue: normal }\end{array}$ & Liveborn \\
\hline Low risk & $\begin{array}{l}\text { Thick nuchal translucency, PRUV, short long } \\
\text { bones, dextrocardia, HLH, VSD, PS }\end{array}$ & Amnio: normal & TOP \\
\hline Low risk† & CPC, AVSD, clenched hands & Amnio: trisomy 18 & TOP \\
\hline Low risk, male & $\begin{array}{l}\text { Female phenotype, cystic hygroma, } \\
\text { ventriculomegaly, AVSD }\end{array}$ & Amnio: $46 \mathrm{XY}$ & TOP \\
\hline
\end{tabular}

Abbreviations: Amnio = amniocentesis; AVSD = atrioventricular septal defect; CPC = choroid plexus cyst; CVS = chorionic villi sampling; $\mathrm{HLH}=$ hypoplastic left heart; IUGR = intrauterine growth restriction; NIPT = non-invasive prenatal testing; PRUV = persistent right umbilical vein; $\mathrm{PS}=$ pulmonary stenosis; $T O P=$ termination of pregnancy; $\mathrm{VSD}=$ ventricular septal defect

* Down's syndrome screening positive for trisomy 21,18 and 13

† Down's syndrome screening for trisomy 18, but patient opted for self-financed second tier NIPT

was offered as a research expense, and the uptake rates were $62 \%$ and $90 \%$, respectively. 13,16

Non-invasive prenatal testing is popular and widely accepted in other parts of the world. The United Kingdom has the same algorithm to manage women screened positive for Down's syndrome, but outside the research arena, NIPT is only available in the private sector at the patient's own expense. A study in the United Kingdom showed that the main motivation for women choosing NIPT as a further test after positive Down's syndrome screening was reassurance, as NIPT is safe, accurate, and able to pick up those that may otherwise have been missed by combined Down's syndrome screening. ${ }^{17}$ The reassurance and reduction of anxiety made all women in the study believe that NIPT should be adopted as part of the National Health System's obstetric practice. Another study in Australia also reported positive experiences in women undergoing NIPT, with $93 \%$ of respondents indicating support of public funding for NIPT as part of Down's syndrome screening. ${ }^{18}$ 
TABLE 3. Demographic and clinical characteristics of women choosing non-invasive prenatal testing versus invasive diagnostic procedures after positive Down's syndrome screening*

\begin{tabular}{|c|c|c|c|}
\hline & NIPT $(n=351)$ & $\begin{array}{l}\text { Invasive procedure } \\
(n=160)\end{array}$ & P value $\neq$ \\
\hline Age (years) & & & 0.846 \\
\hline$<35$ & 139 (39.6\%) & $65(40.6 \%)$ & \\
\hline$\geq 35$ & $212(60.4 \%)$ & 95 (59.4\%) & \\
\hline Education & & & $<0.001$ \\
\hline Primary & $5(1.4 \%)$ & $8(5.0 \%)$ & \\
\hline Secondary & $157(44.7 \%)$ & $92(57.5 \%)$ & \\
\hline Tertiary & $154(43.9 \%)$ & 35 (21.9\%) & \\
\hline Unknown & 35 (10.0\%) & 25 (15.6\%) & \\
\hline Family history† & & & 0.178 \\
\hline No & 349 (99.4\%) & $156(98.1 \%)$ & \\
\hline Yes & $2(0.6 \%)$ & $3(1.9 \%)$ & \\
\hline History of abnormal pregnancy & & & 1.000 \\
\hline No & $343(97.7 \%)$ & $157(98.1 \%)$ & \\
\hline Yes & $8(2.3 \%)$ & $3(1.9 \%)$ & \\
\hline Ethnicity & & & 0.322 \\
\hline Chinese & 345 (98.3\%) & $155(96.9 \%)$ & \\
\hline Non-Chinese & $6(1.7 \%)$ & $5(3.1 \%)$ & \\
\hline Conception by assisted reproductive technology & & & 0.005 \\
\hline No & $322(91.7 \%)$ & $157(98.1 \%)$ & \\
\hline Yes & $29(8.3 \%)$ & $3(1.9 \%)$ & \\
\hline Gravidity & & & $<0.001$ \\
\hline$<3$ & $248(70.7 \%)$ & 75 (46.9\%) & \\
\hline$\geq 3$ & $103(29.3 \%)$ & $85(53.1 \%)$ & \\
\hline Parity & & & $<0.001$ \\
\hline 0 & $189(53.8 \%)$ & $45(28.1 \%)$ & \\
\hline$\geq 1$ & $162(46.2 \%)$ & $115(71.9 \%)$ & \\
\hline Time at DS & & & 0.019 \\
\hline 1st trimester & $317(90.3 \%)$ & $132(82.5 \%)$ & \\
\hline 2nd trimester & $34(9.7 \%)$ & $28(17.5 \%)$ & \\
\hline DS positive & & & $<0.001$ \\
\hline Any one of trisomy 13,18 , or 21 positive & $310(88.3 \%)$ & $109(68.1 \%)$ & \\
\hline More than one positive & $41(11.7 \%)$ & $51(31.9 \%)$ & \\
\hline Nuchal translucency thickness $(\mathrm{mm}) \dagger$ & & & $<0.001$ \\
\hline$<3$ & $300(85.5 \%)$ & $108(67.9 \%)$ & \\
\hline 3.3-3.49 & 33 (9.4\%) & $15(9.4 \%)$ & \\
\hline$\geq 3.5$ & $18(5.1 \%)$ & $36(22.6 \%)$ & \\
\hline Trisomy 21 adjusted term risk & & & $<0.001$ \\
\hline $1-9$ & $42(12.0 \%)$ & $53(33.1 \%)$ & \\
\hline $10-99$ & $122(34.8 \%)$ & 55 (34.4\%) & \\
\hline $100-199$ & 126 (35.9\%) & $36(22.5 \%)$ & \\
\hline $200-250$ & 61 (17.4\%) & 16 (10.0\%) & \\
\hline
\end{tabular}

Abbreviations: DS = Down's syndrome; NIPT = non-invasive prenatal testing

* Data are presented as No. (\%)

+ Data missing for one subject in the invasive procedure group

‡ P values were calculated by Chi squared test or Fisher's exact test 
TABLE 4. Local studies about second tier non-invasive prenatal testing after high-risk Down's syndrome screening results

\begin{tabular}{|c|c|c|c|c|c|}
\hline Studies & Poon et al, $2015^{10}$ & Chan et al, $2015^{11}$ & Cheng et al, $2018^{16}$ & Lo et al, $2019^{13}$ & Present study \\
\hline Study period & $8 / 2011-7 / 2013$ & $1 / 2012-6 / 2013$ & $7 / 2015-4 / 2016$ & $7 / 2015-6 / 2016$ & 1/1/2015-31/12/2016 \\
\hline $\begin{array}{l}\text { Study duration } \\
\text { (months) }\end{array}$ & 24 & 18 & 10 & 12 & 24 \\
\hline Study nature & Retrospective & Retrospective & Prospective & Prospective & Retrospective \\
\hline Study setting & $\begin{array}{l}\text { Regional public } \\
\text { obstetrics unit (QEH) }\end{array}$ & $\begin{array}{l}\text { Regional public } \\
\text { obstetrics units } \\
\left(\mathrm{PWH}^{\star}, \mathrm{PMH}, \mathrm{KWH}\right)\end{array}$ & $\begin{array}{l}\text { Regional public } \\
\text { obstetrics units }(\mathrm{KWH} \text {, } \\
\left.\mathrm{PWH}^{\star}, \mathrm{QEH}\right)\end{array}$ & $\begin{array}{l}\text { Regional public } \\
\text { obstetrics units (TYH/ } \\
\text { QMH }^{\star}, \text { QEH, UCH, } \\
\text { PYNEH, TMH) }\end{array}$ & $\begin{array}{l}\text { Regional public } \\
\text { obstetrics unit (KWH) }\end{array}$ \\
\hline $\begin{array}{l}\text { No. of women } \\
\text { included in the study }\end{array}$ & 76 & 125 & 347 & 231 & 525 \\
\hline $\begin{array}{l}\text { Timing of Down's } \\
\text { syndrome screening }\end{array}$ & $\begin{array}{l}\text { 1st trimester, } 687 \\
(90.0 \%) \\
\text { 2nd trimester, } 76 \\
(10.0 \%)\end{array}$ & $\begin{array}{l}\text { 1st trimester, } 905 \\
(72.3 \%) \\
\text { 2nd trimester, } 346 \\
(27.7 \%)\end{array}$ & $\begin{array}{l}\text { 1st trimester, } 304 \\
(87.6 \%) \\
\text { 2nd trimester, } 43 \\
(12.4 \%)\end{array}$ & Not available & $\begin{array}{l}\text { 1st trimester, } 459 \\
(87.4 \%) \\
\text { 2nd trimester, } 66 \\
(12.6 \%)\end{array}$ \\
\hline Definition of high risk & $\geq 1: 250$ & $\geq 1: 250$ & $\geq 1: 250$ & $\geq 1: 250$ & $\geq 1: 250$ \\
\hline NIPT charges & Self-financed & Self-financed & Funded by research & Funded by research & $\begin{array}{l}\text { Self-financed or } \\
\text { funded by research } †\end{array}$ \\
\hline $\begin{array}{l}\% \text { choosing NIPT } \\
(95 \% \mathrm{Cl})\end{array}$ & $20 \%(18 \%-24 \%)$ & $29 \%(26 \%-32 \%)$ & $62 \%(57 \%-67 \%)$ & $90 \%(85 \%-93 \%)$ & $67 \%(63 \%-71 \%)$ \\
\hline $\begin{array}{l}\text { Diagnostic extent of } \\
\text { NIPT }\end{array}$ & Trisomies 21, 13, 18 & $\begin{array}{l}\text { Contemporary } \\
\text { commercial spectrum }\end{array}$ & $\begin{array}{l}\text { Trisomies } 21,13,18, \\
\text { and sex chromosomes }\end{array}$ & Standard vs extended & $\begin{array}{l}\text { Contemporary } \\
\text { commercial spectrum }\end{array}$ \\
\hline $\begin{array}{l}\text { Factors } \\
\text { independently } \\
\text { associated with NIPT } \\
\text { uptake }\end{array}$ & $\begin{array}{l}\text { Nulliparity, working } \\
\text { women, first trimester } \\
\text { screening }\end{array}$ & $\begin{array}{l}\text { Nulliparity, } \\
\text { conception by } \\
\text { assisted reproductive } \\
\text { technology }\end{array}$ & $\begin{array}{l}\text { Nuchal translucency } \\
<3.5 \mathrm{~mm} \text {, adjusted } \\
\text { term risk }<1: 9\end{array}$ & $\begin{array}{l}\text { Maternal age } \geq 35 \\
\text { years, adjusted term } \\
\text { risk } 1: 126-250 \text { (data } \\
\text { from Lo et al, 2017) }\end{array}$ & $\begin{array}{l}\text { Nulliparity, higher } \\
\text { education, gravidity } \\
<3 \text {, first trimester } \\
\text { screening }\end{array}$ \\
\hline $\begin{array}{l}\% \text { choosing direct } \\
\text { invasive diagnostic } \\
\text { tests }\end{array}$ & $68 \%$ & $67 \%$ & $37 \%$ & $10 \%$ & $31 \%$ \\
\hline $\begin{array}{l}\text { Diagnostic extent of } \\
\text { invasive diagnostic } \\
\text { tests }\end{array}$ & Karyotyping & Karyotyping & Karyotyping + CMA & Karyotyping & $\begin{array}{l}\text { Karyotyping } \pm \\
\text { chromosomal } \\
\text { microarray } \dagger\end{array}$ \\
\hline NIPT results & Not available & Not available & $\begin{array}{l}\text { Abnormal (8\%); normal } \\
(92 \%)\end{array}$ & $\begin{array}{l}\text { Abnormal/inconclusive } \\
(8 \%) ; \text { normal }(92 \%)\end{array}$ & $\begin{array}{l}\text { Abnormal/inconclusive } \\
(7 \%) ; \text { normal }(93 \%)\end{array}$ \\
\hline
\end{tabular}

Abbreviations: 95\% Cl = 95\% confidence interval; CMA = chromosomal microarray; $\mathrm{KWH}=$ Kwong Wah Hospital; NIPT = non-invasive prenatal testing; $\mathrm{PMH}=$ Princess Margaret Hospital; PWH = Prince of Wales Hospital; PYNEH = Pamela Youde Nethersole Eastern Hospital; QEH = Queen Elizabeth

Hospital; QMH = Queen Mary Hospital;TMH = Tuen Mun Hospital;TYH = Tsan Yuk Hospital; UCH = United Christian Hospital

* University-affiliated obstetrics units

† 39 (7\%) women included in this study were also recruited to Cheng et al's study ${ }^{16}$

In concordance with high acceptance of NIPT in Hong Kong and worldwide, the number of invasive procedures has significantly decreased recently. In our study, 328 (62\%) women were able to avoid unnecessary invasive diagnostic procedures that might have been performed in historical clinical practice in public hospitals before NIPT and current clinical practice if these pregnant women are not able to pay the cost. Uptake may be much greater if NIPT is offered at no cost. Second tier screening after positive combined first trimester screening significantly reduced the number of invasive procedures performed and increased specificity while maintaining close to $100 \%$ sensitivity. ${ }^{19}$ In addition, NIPT may provide a broader range of information about microdeletions, microduplications, singlegene disorders, etc. This provides additional options for women who prefer the extended reports provided by NIPT if clinically indicated. ${ }^{20}$

Although NIPT is highly sensitive and specific in detecting trisomies 21,18 , and 13 , ultrasound still plays an important complementary role in the contemplated algorithm for prenatal Down's syndrome screening. Given normal NIPT results following positive Down's syndrome screening, a number of women may also require invasive procedures in the presence of sonographic abnormalities resulting from false negative cases or non-aneuploidy diseases like thalassaemia (Table 2).

We reviewed the local data from studies in Hong Kong regarding second tier NIPT after highrisk Down's syndrome screening results (Table $\left.4^{10,11,13,16,21}\right)$. Our study has the largest sample size in the last 5 years. The vast majority of pregnant women presented to the obstetrics unit during the first trimester and had first trimester combined 
Down's syndrome screening tests performed. In non-research (self-financed NIPT) settings, NIPT uptake rates have been increasing since 2011. Nulliparity, first trimester status, higher education, maternal employment, and conception by assisted reproductive technology are common factors that have been independently associated with selffinanced NIPT after positive Down's syndrome screening tests. In our study, a multivariable logistic regression model indicated that NT thickness and adjusted term risk ratio of trisomy 21 were no longer statistically associated with NIPT uptake. We found that positive Down's syndrome screening results, adjusted term risk of trisomy 21, and NT were correlated. By controlling for any one of these factors, the effects of the other two factors could be held relatively constant. Moreover, NT thickness is only reported in the first trimester, and therefore, the effects of NT may be accounted for by the first trimester factor. Among women choosing NIPT, the rate of abnormal results has typically been around $8 \%$ in studies performed in Hong Kong.

Our study is limited by the retrospective nature of the study and missing data on selfreported items like education level and household income. Furthermore, obstetric professionals' perceptions about NIPT may vary among different healthcare providers, leading to potential implicit bias. ${ }^{22}$ Studies have found that obstetricians had more certain views about the usefulness of NIPT than midwives had. ${ }^{23}$ To consider this potential bias, a questionnaire to the healthcare providers would be useful for understanding their perceptions, attitudes, and the extent of any bias towards NIPT or invasive diagnostic procedures. Standardised counselling materials (interview scripts, booklets, videos, question and answer information sheets) distributed to women may also minimise dynamic human factors during the counselling session.

\section{Conclusion}

Implementation of second tier NIPT in the public setting is believed to improve quality of care, women's choice, and overall financial/budget performance. ${ }^{24}$ A significant number of unnecessary invasive procedures can be avoided. We expect that the public in Hong Kong will welcome this new policy.

\section{Author contributions}

All authors had full access to the data, contributed to the study, approved the final version for publication, and take responsibility for its accuracy and integrity.

Concept or design: VKS Ng.

Acquisition of data: VKS Ng.

Analysis or interpretation of data: VKS Ng.

Drafting of the article: VKS Ng.

Critical revision for important intellectual content: AL Chan, WL Lau, WC Leung.

\section{Conflicts of interest}

The authors have no conflicts of interest or declarations to report regarding the present work.

\section{Acknowledgement}

The authors acknowledge the excellent work by staff at the prenatal diagnostic clinic, Kwong Wah Hospital for their outstanding service provision and patient care.

\section{Funding/support}

This research received no specific grant from any funding agency in the public, commercial, or not-for-profit sectors.

\section{Ethics approval}

This study protocol was reviewed and approved by the Research Ethics Committee (Kowloon Central/Kowloon East) of the Hong Kong Hospital Authority (Ref no. KC/KE-180123/ER-3). The requirement for patient consent was waived by the Ethics Committee.

\section{References}

1. Benn P, Borrell A, Chiu RW, et al. Position statement from the Chromosome Abnormality Screening Committee on behalf of the Board of the International Society for Prenatal Diagnosis. Prenat Diagn 2015;35:725-34.

2. Sahota DS, Leung WC, Chan WP, To WW, Lau ET, Leung TY. Prospective assessment of the Hong Kong Hospital Authority universal Down syndrome screening programme. Hong Kong Med J 2013;19:101-8.

3. Lo TK, Lai FK, Leung WC, et al. Screening options for Down syndrome: how women choose in real clinical setting. Prenat Diagn 2009;29:852-6.

4. Tu S, Rosenthal M, Wang D, Huang J, Chen Y. Performance of prenatal screening using maternal serum and ultrasound markers for Down syndrome in Chinese women: a systematic review and meta-analysis. BJOG 2016;123 Suppl 3:12-22.

5. Lo YM, Corbetta N, Chamberlain PF, et al. Presence of fetal DNA in maternal plasma and serum. Lancet 1997;350:4857.

6. Chiu RW, Chan KC, Gao Y, et al. Noninvasive prenatal diagnosis of fetal chromosomal aneuploidy by massively parallel genomic sequencing of DNA in maternal plasma. Proc Natl Acad Sci U S A 2008;105:20458-63.

7. Chiu RW, Akolekar R, Zheng YW, et al. Non-invasive prenatal assessment of trisomy 21 by multiplexed maternal plasma DNA sequencing: large scale validity study. BMJ 2011;342:c7401.

8. Dondorp W, de Wert G, Bombard Y, et al. Non-invasive prenatal testing for aneuploidy and beyond: Challenges of responsible innovation in prenatal screening. Eur J Hum Genet 2015;23:1438-50.

9. Gil MM, Accurti V, Santacruz B, Plana MN, Nicolaides KH. Analysis of cell-free DNA in maternal blood in screening for aneuploidies: updated meta-analysis. Ultrasound Obstet Gynecol 2017;50:302-14.

10. Poon CF, Tse WC, Kou KO, Leung KY. Uptake of noninvasive prenatal testing in Chinese women following positive down syndrome screening. Fetal Diagn Ther 2015;37:141-7.

11. Chan YM, Leung WC, Chan WP, Leung TY, Cheng YK, 
Sahota DS. Women's uptake of non-invasive DNA testing following a high-risk screening test for trisomy 21 within a publicly funded healthcare system: findings from a retrospective review. Prenat Diagn 2015;35:342-7.

12. Kwong Wah Hospital, Hospital Authority, Hong Kong SAR Government. Annual Report 2012-2016, Department of Obstetrics and Gynaecology, Kwong Wah Hospital.

13. Lo TK, Chan KY, Kan AS, et al. Decision outcomes in women offered noninvasive prenatal test (NIPT) for positive Down screening results. J Matern Neonatal Med 2019;32:348-50.

14. Lo TK, Chan KY, Kan AS, et al. Effect of knowledge on women's likely uptake of and willingness to pay for noninvasive test (NIPT). Eur J Obstet Gynecol Reprod Biol 2018;222:183-4.

15. Riphahn RT, Serfling O. Item non-response on income and wealth questions. Empir Econ 2005;30:521-38.

16. Cheng Y, Leung WC, Leung TY, et al. Women's preference for non-invasive prenatal DNA testing versus chromosomal microarray after screening for Down syndrome: a prospective study. BJOG 2018;125:451-9.

17. Lewis C, Hill M, Chitty LS. Women's experiences and preferences for service delivery of non-invasive prenatal testing for aneuploidy in a public health setting: a mixed methods study. PLoS One 2016;11:e153147.

18. Bowman-Smart H, Savulescu J, Mand C, et al. 'Small cost to pay for peace of mind': women's experiences with non- invasive prenatal testing. Aust N Z J Obstet Gynaecol 2019;59:649-55

19. Miltoft CB, Rode L, Ekelund CK, et al. Contingent firsttrimester screening for aneuploidies with cell-free DNA in a Danish clinical setting. Ultrasound Obstet Gynecol 2018;54:470-9.

20. Lo TK, Chan KY, Kan AS, et al. Study of the extent of information desired by women undergoing non-invasive prenatal testing following positive prenatal Downsyndrome screening test results. Int J Gynecol Obstet 2017;137:338-9.

21. Lo TK, Chan KY, Kan AS, et al. Informed choice and decision making in women offered cell-free DNA prenatal genetic screening. Prenat Diagn 2017;37:299-302.

22. FitzGerald $C$, Hurst S. Implicit bias in healthcare professionals: a systematic review. BMC Med Ethics 2017;18:19.

23. Ngan OM, Yi H, Wong SY, Sahota D, Ahmed S. Obstetric professionals' perceptions of non-invasive prenatal testing for Down syndrome: clinical usefulness compared with existing tests and ethical implications. BMC Pregnancy Childbirth 2017;17:285.

24. Chitty LS, Wright D, Hill M, et al. Uptake, outcomes, and costs of implementing non-invasive prenatal testing for down syndrome into NHS maternity care: Prospective cohort study in eight diverse maternity units. BMJ 2016;354:i3426. 